\title{
Pensjonaty pamięci, odłamki wspomnień
}

Ten, kto pierwszy orzekł, że czas goi rany, zapomniał o jego dotkliwości i przemijaniu, które w sposób oczywisty oznaczają utratę, coraz szybszy wraz z bagażem lat kurs w stronę nicości. Mija wszystko, dobre i złe, nie ma nic trwałego na świecie i rzeka Heraklita - jak powszechnie wiadomo - wciąż odmienia swe wody. Dar pamięci pozwala zachować ciągłość istnienia, z okruchów codzienności układać historię życia, z plączących się nitek samoświadomej refleksji snuć opowieść tożsamościową. W jakimś stopniu pomaga oswajać powiększający się rejestr strat i podsuwa pociechę w postaci iluzji trwania wbrew wszelkiej oczywistości kurczącego się czasu.

Archiwa chwil minionych, albumy wyblakłych fotografii, sanatoria żałoby, "pensjonaty pamięci” - na różne sposoby próbujemy ingerować w czas, by cofnać go „o pewien interwał, którego wielkości niepodobna określić" ${ }^{1}$. Nieprawomyślne i wysoce podejrzane eksperymenty z czasem Doktora Gotarda z opowiadania Brunona Schulza prócz obietnicy niosą z sobą jednak nieuchronne rozczarowanie. „Cofnięty czas... w samej rzeczy pięknie to brzmi, ale czymże okazuje się $\mathrm{w}$ istocie? [...] Jest to do cna zużyty, znoszony przez ludzi czas, czas przetarty i dziurawy w wielu miejscach, przeźroczysty jak sito"2. Dla tych, którzy utracili wszystko, ów „czas z drugiej ręki”3 bywa jedyną szansą.

Tony Judt, wybitny historyk chorujący na stwardnienie zanikowe boczne, w ostatnich latach swego życia przeniósł się do „pensjonatu

${ }^{1}$ B. Schulz: Sanatorium pod Klepsydra. W: IDEm: Opowiadania. Wybór esejów i listów. Oprac. J. JARzęBsKi. Wrocław-Warszawa-Kraków-Gdańsk-Łódź 1989, s. 254.

2 Ibidem, s. 268.

${ }^{3}$ Ibidem. 
pamięci". Wyłączony z wszelkich form aktywności, pozbawiony umiejętności samodzielnego pisania, tracący głos, ale jednak zachowujący jasny i przenikliwy umysł, oddawał się narracjom, snutym na granicy jawy i snu:

Niewątpliwie szukałem sposobu, by zasnąć, zastępując niezdarne barany złożoną narracją - z podobnym skutkiem. W trakcie tych ćwiczeń uświadomiłem sobie jednak, że odtwarzam - jakby z klocków Lego - przeplatające się fragmenty przeszłości, o których nigdy bym wcześniej nie pomyślał, że mają ze sobą związek

Judt praktykował wszak coś więcej niż tylko zwykłe wspominanie, nie o nostalgiczne wycieczki mu bowiem chodziło, a o zbudowanie przejrzystej struktury, opartej na mnemotechnicznych metodach podróżników początków ery nowożytnej, tworzących „pałace pamięci”. Ich ekstrawagancje Judt dostosował do realiów swego życia i mentalnie wrócił do znanego sobie doskonale pensjonatu $\mathrm{w}$ Chesières w Szwajcarii, w którym spędzał niegdyś zimowe wakacje i który był w stanie drobiazgowo odtworzyć. Gdyby oddawał się zwykłym "ćwiczeniom pamięci", dowodzeniu jej szczegółowości i wierności, nie byłoby $w$ tym nic nadzwyczajnego. Judt jednak zamienił swą pamięć $\mathrm{w}$ swoisty mechanizm, zorganizowany przestrzennie - na wzór pensjonatu $\mathrm{z}$ lat dzieciństwa. Krocząc zatem po dobrze znanych ścieżkach, „wyzwalał” wspomnienia i przeobrażał swą pamięć w „magazyn danych”. Precyzja działania pamięciowej mapy, wyznaczonej przez umysł uwięziony w ciele, zadziwia i zachwyca. Judt powiada: „wyczarowuję, segreguję i porządkuję opowieść" ${ }^{\prime \prime} \mathrm{i}$ właśnie ów porządek, zyskiwany podczas mentalnych przechadzek, jest tak urzekający. Rytm opowieści budowany jest na podstawie wyobrażonego rytmu chodzenia, „mikrogeografii” odtwarzanych w pamięci szlaków:

Kiedy już mniej więcej wiem, co chcę powiedzieć, i w jakiej kolejności najlepiej to wyrazić, wstaję z fotela i podchodzę z powrotem do drzwi wejściowych. Stąd wracam tą samą drogą, kierując się przeważnie od pierwszego schowka [...] ku większym przestrzeniom [...], po czym wchodzę do któregoś z pokojów. Do każdego z tych miejsc przypisany jest jakiś istotny fragment opowieści albo, dajmy na to, wyjaśniający przykład ${ }^{6}$.

4 T. Judt: Pensjonat pamięci. Przeł. H. Jankowska. Wołowiec 2012, s. 15.

${ }^{5}$ Ibidem, s. 16.

${ }^{6}$ Ibidem, s. 16-17. 
Ciało Judta, poddane neurodegeneracyjnym zmianom, kroczy więc korytarzem pamięci, a tym samym przełamuje chorobowy impas, bezwolność i niemoc zastępuje uporządkowaniem. Porządek wydaje się we wstępnych założeniach systemu Judta kluczem, skądinąd nieco przecenianym. Autor ma pełną tego świadomość, zauważając przytomnie, że "wszystko się na siebie nakłada"7 , że dochodzi do "pomieszania wrażeń i wspomnień"8. Zdarzają się zatem noce bezproduktywne, pozostawione „wiecznie niezadowolonemu alter ego" ${ }^{\prime \prime}$, przynoszące tylko natrętne wspomnienia utraty jakości życia, aktywności, zdrowia. Judt pisze:

Są jednak noce, kiedy [...] [wszystko - J.K., M.Ł.] działa jak należy. Twarze powracają, przykłady pasują, ożywają sepiowe fotografie, „wszystko się układa”. W ciągu kilku minut mam już swoją opowieść, postacie, ilustracje i morał. [...] Otacza mnie przeszłość i mam to, czego mi potrzeba ${ }^{10}$.

Zauważona ambiwalencja pamięci przekłada się na zasadniczo inną formę pisania, odróżniającą się „impresjonistycznym efektem”. Pisarz logikę, prawdopodobieństwo, dowodzenie - cały swój dotychczasowy warsztat historyka - zamienia na przedziwny węzeł, w którym spotykają się „prywatne z publicznym, wyrozumowane $\mathrm{z}$ intuicyjnym, przypomniane $\mathrm{z}$ odczuwanym"111. Efekt przechadzek po ścieżkach pensjonatu pamięci jest z pewnością bardziej ludzki, naznaczony ciałem, ale przecież nie sposób zapomnieć, że „zawdzięcza" to ciału-mumii, lotnemu umysłowi uwięzionemu w "żelaznym pancerzu".

Zdaje się, że kondycja Judta dość dobrze obrazuje meandry pamięci. Aby znieść powtarzającą się mękę nocy, pisarz przywołuje wspomnienia, budując $\mathrm{z}$ nich $\mathrm{w}$ sieci własnej pamięci strukturę przetrwania. Świadomy jej jasnych stron, zauważa jednak z nieusuwalną goryczą: „Moje noce są ciekawe, ale mógłbym obejść się bez nich"12. Nie chodzi tylko o fakt, że wizyty w nawet najlepiej urządzonym „pensjonacie pamięci" są w jego wypadku formą kompensacji niemożliwej aktywności i samodzielności.

\footnotetext{
${ }^{7}$ Ibidem, s. 17.

8 Ibidem, s. 19.

${ }^{9}$ Ibidem.

${ }^{10}$ Ibidem, s. 19-20.

11 Ibidem, s. 20.

12 Ibidem, s. 28.
} 
Praktyki pamięciowe mają wszak ciemne strony, wiążą się $\mathrm{z}$ afektami, reakcjami somatycznymi, traumą. Walcząc o pamięć i z pamięcią, stajemy jednak wobec możliwości, by zobaczyć więcej. Pisał o tym Marek Zaleski, zwracając uwagę na splot powtórzenia i opóźnienia: „Rzeczywistość, powracająca w pamięci, jawi się w powtórzeniu (i tym samym w opóźnieniu). Poprzez opóźnienie właściwe powtórzeniu to, co przedstawione, istnieje wyraźniej"13. Tkanka pamięci bywa zatem jak żywa rana, kaleczy, zadaje ból, stawia przed wyjaskrawionym obrazem, zarysowanym inaczej - ostrzej - niż kiedyś. Proces uaktualnienia nie oznacza przecież zwykłej rekonstrukcji, przypomina raczej odgrywanie, reżyserowanie zdarzeń na nowo, często niemal detektywistyczną pracę od-twarzania tego, co przykryła mgła (nie)pamięci.

Co ważniejsze jednak, jak zauważa Wojciech Kalaga:

Akt pamiętania jest jednocześnie aktem interpretacji - wyborem tej a nie innej ścieżki interpretacyjnej, tej a nie innej perspektywy i jednocześnie swego rodzaju zapominaniem - pomijaniem innych perspektyw i innych możliwości interpretacji. Nie należy oczywiście przyjmować, iż to podążanie ścieżkami interpretacyjnymi ma charakter logicznego ciągu wnioskowań; przeciwnie jest, jak powiedziałby właśnie logik - entymematyczne, tzn. fragmentaryczne, zawierające luki, przeskoki i pominięcia. Jednakże ta fragmentaryczność czytania znaków pamięci w niczym nie zmienia jej interpretacyjnego charakteru ${ }^{14}$.

Rekonstrukcja, inscenizacja i interpretacja czasu minionego nie dokonują się na chłodno. Proces tożsamościowy, budowany na tropach pamięci, wymaga czasu i równoważenia emocji. Boli świadomość utraty i ranią odłamki złych wspomnień. Utrwalone w filozoficznej tradycji konceptualizacje pamięci, przywołujące modele przestrzenne - woskowe tabliczki Platona i Arystotelesa, stopniowo zapełniane gabloty Johna Locke’a, pałace pamięci św. Augustyna, a później aktualne aż po współczesność archiwalne ujęcia, sugerujące gromadzenie, utrwalanie i przechowywanie wspomnień, mają charakter statyczny, zapewniający niezmienność zdeponowanego materiału, dopuszczający jedynie jego przyrost. A przecież treści pamięci podlegają nieustannej reinterpretacji, wchodzą $\mathrm{w}$ wielorakie

${ }^{13}$ M. Zaleski: Formy pamięci. O przedstawianiu przeszłości w polskiej literaturze współczesnej. Gdańsk 2004, s. 7.

${ }^{14}$ W. Kalaga: Pamięć, interpretacja, tożsamość. „Teksty Drugie” 2012, nr $1 / 2$, s. 71. 
relacje między sobą i przybywającymi z czasem nowymi doświadczeniami, aktualizowane są wybiórczo, niekoniecznie zgodnie z wola podmiotu. Kalaga pisze:

Jeżeliby więc chcieć traktować pamięć jako tekst, jak to się czasami czyni, to musiałby to być tekst $\mathrm{w}$ nieprzerwanym działaniu, tekst niestały, niestabilny, dostępny jedynie w swych kolejnych interpretacjach, pozbawiony jakiegokolwiek esencjalnego bytu od interpretacji niezależnego ${ }^{15}$.

Pamięć jako budulec tożsamości wymusza czujność i aktywność podmiotu, wdziera się w jego świadomość, wciąga w sprawy nieodwołalnie skończone w czasie, choć nigdy niezamknięte ostatecznie. Idea pensjonatu pamięci, idyllicznego obrazu przeszłości, w którym można się schronić przed niedogodnościami i okrucieństwem losu, przynosi ulgę tylko do pewnego stopnia. To ścieżka marzenia, odmowa rzeczywistości, romantyczny gest powrotu do „ojczyzny myśli", ujawniający jednak bolesne rozdarcie między aktualnością nie do zniesienia i mentalną ucieczką $\mathrm{w}$ rejony niedotknięte jeszcze nieszczęściem.

Podróż Józefa do „Sanatorium pod Klepsydrą” w odwiedziny do zmarłego ojca przenosi bohatera opowiadania Schulza w przestrzeń pamięci mglistej, niestabilnej i meandrycznej, pozostawia go zagubionego między świadomością śmierci starego Jakuba i rozpoznawaniem jego zdegradowanej, połowicznej egzystencji w sanatorium żałoby. W pamięciowym powtórzeniu ostrzej i dramatyczniej ujawni się też kondensacja ambiwalentnych synowskich emocji. $Z$ sennego labiryntu żałobnego miasteczka ostatecznie Józef salwuje się ucieczką, zaniechawszy pożegnania z ojcem. Dar pamięci umożliwi mu wprawdzie spotkanie ze zmarłym, jej dotkliwość ujawni jednak z całą jaskrawością niemożliwy do rozsupłania węzeł afektów, niezrozumiały splot nakładających się na siebie obrazów, a nade wszystko problem tożsamościowy bohatera, początkowo bezskutecznie szukającego swego odbicia w lustrze, ostatecznie natomiast skrywającego obolałą twarz za brudną chustką. Kondycja Józefa po pobycie $\mathrm{w}$ sanatorium niezagojonej pamięci przejmie na siebie jej żałobny klimat, a los bohatera zdominuje znużenie bezsensownej podróży o nieokreślonym celu, zaniedbanym pociągiem pełnym przeciągów i śmieci.

15 Ibidem, s. 72. 
Czy czas leczy rany, a blizny raczej znaczą niż bolą? Oczywiście, choć zdarza się tak nie tylko wtedy, gdy bolesną przeszłość okryje mgła zapomnienia, ale także wówczas, gdy wątki pamięciowe udaje się zinterpretować i przynajmniej czasowo ująć w ramy pogodnego, pięknego obrazu. Dotkliwa praca pamięci znajduje wtedy wytchnienie, a jej efekt może nawet zastygnąć na kształt flamandzkiego dzieła sztuki, korzystającego z tajemnicy wydobywania blasku z mrocznej scenerii, jak w znanym wierszu Wisławy Szymborskiej:

Pamięć nareszcie ma, czego szukała.

Znalazła mi się matka, ujrzał mi się ojciec.

Wyśniłam dla nich stół, dwa krzesła. Siedli.

Byli mi znowu swoi i znowu mi żyli.

Dwoma lampami twarzy o szarej godzinie

błyśli jak Rembrandtowi.

$[\ldots]^{16}$

W onirycznym kształcie pięknego snu: „Zdawali mi się długo, długo i szczęśliwie"17, pamięć przybiera formę statyczną, fotografii $\mathrm{z}$ albumu, gotowej do akceptacji i złożenia w archiwum rodzinnej przeszłości. Szczęśliwa chwila wytchnienia („nareszcie”) ma jednak $\mathrm{w}$ wierszu przeciwwagę $\mathrm{w}$ postaci splątanych ścieżek snów lękowych, natrętnych, niewypowiadalnych, pełnych pamięciowych obrazów, dramatyzowanych przez mechanizmy neurotycznego poczucia winy:

Teraz dopiero mogę opowiedzieć, w ilu snach się tułali, w ilu zbiegowiskach spod kół ich wyciągałam, $\mathrm{w}$ ilu agoniach przez ile mi lecieli rąk.

Odcięci - odrastali krzywo.

Niedorzeczność zmuszała ich do maskarady.

Cóż stąd, że to nie mogło ich poza mną boleć,

Jeśli bolało ich we mnie. $[\ldots]^{18}$

Archiwum oswojonej pamięci w psychicznym doznaniu podmiotu jest doświadczeniem chwili, statyczny obraz szczęśliwej przeszłości

${ }^{16}$ W. Szymborska: Pamięć nareszcie. W: Eadem: Wybór poezji. Wstęp i oprac. W. Ligęza. Wrocław 2016, s. 131.

${ }^{17}$ Ibidem, s. 132.

${ }^{18}$ Ibidem, s. 131. 
jawi się pośród innych, niespokojnych, drażniących i bolesnych. Pamięć zawsze inscenizowana, dopełniana i przekształcana, nieustannie pulsuje, chwiejna i niestabilna, litościwa i chimeryczna na przemian. Prowokuje trud interpretacji, wymusza nieprzerwana przebudowę narracyjnej tożsamości podmiotu. W późniejszym o przeszło czterdzieści lat wierszu noblistki Trudne życie z pamięcia czytamy:

Jestem złą publicznością dla swojej pamięci.

Chce, żebym bezustannie słuchała jej głosu,

a ja się wiercę, chrząkam,

słucham i nie słucham,

wychodzę, wracam i znowu wychodzę.

$[\ldots]^{19}$

Uciążliwa i nużąca, dotkliwa i skrupulatna, czasem mściwa, innym razem łaskawa pamięć, zaangażowana $\mathrm{w}$ tożsamościowe procesy i przemiany, póki działa, domaga się uwagi i reakcji. Te uparte ingerencje w porządek(?) myśli i zaułki snu współtworzą dynamikę podmiotu, jego tożsamość budowaną w procesie dopełnień, odwołań i reinterpretacji. Właściwy późnym latom efekt reminiscencji, przymus przywoływania odległego czasu bez emocjonalnego nasycenia wspomnień negatywnych, odsuwa aktualność, rozluźnia z nią związki, unieważnia plany, może więc wywołać także odruch buntu:

Chce, żebym żyła tylko dla niej i z nią.

Najlepiej w ciemnym, zamkniętym pokoju,

a u mnie ciągle w planach słońce teraźniejsze,

obłoki aktualne, drogi na bieżąco.

Czasami mam jej towarzystwa dosyć.

Proponuję rozstanie. Od dzisiaj na zawsze.

Wówczas uśmiecha się z politowaniem,

bo wie, że byłby to wyrok i na mnie ${ }^{20}$.

Witalność podmiotu wiersza nie godzi się na ograniczenie bodźców do tych wyłącznie, które płyną z przeszłości, pozostaje otwarta na nowe ścieżki doznań, przekonana, że nie wszystko już było. Domykający się horyzont życia zacieśnia granice, straszy wizją

19 W. Szymborsкa: Trudne życie z pamięcia. W: EAdem: Wybór poezji..., s. 434.

${ }^{20}$ Ibidem, s. 435. 
ciemnego, zamkniętego pokoju, absorbującego czas i uwagę tym dziwnym tête-à-tête z natłokiem wspomnień. Kim zatem jesteśmy ostatecznie? Swoją pamięcią, lecz czy na pewno swoją? Zwodniczą i niepewną, pełną przekłamań i interpretacyjnych przekształceń? Kim będziemy, jeśli istotnie czeka nas rozstanie z pamięcią? Czy jesteśmy gotowi na przyjęcie nowej, bezprecedensowej osobowości, która zrodzi się - jak pisze filozofka Catherine Malabou - bez związku z naszą przeszłością ${ }^{21}$ ?

Najbardziej znany w świecie neurolog i jednocześnie pisarz Oliver Sacks, wsparty medycznym i humanistycznym doświadczeniem oraz rzetelną wiedzą o mechanizmach funkcjonowania ludzkiego mózgu, konstatuje ponad wszelką wątpliwość:

Nie ma drogi, po której wydarzenia świata mogłyby zostać bezpośrednio przeniesione do naszego mózgu czy w nim utrwalone. Wydarzenia te są bowiem doświadczane i konstruowane w sposób nader subiektywny, który po pierwsze jest bardzo odmienny u każdej jednostki, a po drugie, różnie jest reinterpretowany i ponownie doświadczany, gdy wydarzenia te są przypominane. Jedyną naszą prawdę stanowi prawda narracyjna, prawda opowieści, które przedstawiamy sobie i innym, a które nieustannie rekategoryzujemy i ulepszamy ${ }^{22}$.

Statyczne metafory pamięci, obiektywne i wierne odciski minionych zdarzeń na woskowych tabliczkach, wszelkie zbiorniki do przechowywania przeszłości aktualizują życzeniowe myślenie i wielką blagę. Nie warto ślepo ufać świadectwu pamięci, trudno oprzeć się na jej chwiejnym fundamencie, chyba że poszukamy w niej prawdy świadomościowego procesu, zawierzymy tożsamościowej opowieści. Ułomność pamięci w porządku twórczości i sztuki na wielu poziomach okazuje się wtedy siła, co znakomicie rozpoznał w działaniu memoralnych mechanizmów Sacks:

Każdy z nas, ludzi, obdarzony jest pamięcią, do której właściwości należą zawodność, kruchość, niedoskonałość, ale także ogromna giętkość i twórczość. [...] Obojętność na źródła pozwala nam przyjmować to, co czytamy, co słyszymy, o czym nas powiadamiają, a jednocześnie myśleć, pisać i malować tak intensywnie,

${ }^{21}$ C. Malabou: Ontologia przypadłości. Esej o plastyczności destrukcyjnej. Przeł. i posłowiem opatrzył P. SкALsкi. Warszawa 2017.

${ }^{22}$ O. SAcks: Zawodność pamięci. W: Idem: Rzeka świadomości. Przeł. J. ŁozıńsKi. Poznań 2018, s. 127. 
jak gdyby pochodziło to z bezpośredniego doświadczenia. Dzięki temu możemy widzieć oczyma innych ludzi i słyszeć ich uszami, możemy wchodzić do ich umysłów, przyswajać sobie sztukę, naukę, religię i w ogóle kulturę, wkraczać do niej i wnosić własne elementy do wspólnego bogactwa kultury. Pamięć wyrasta nie tylko z doświadczenia, lecz także ze współdziałania z innymi umysłami ${ }^{23}$.

Joanna Kisiel

iD https://orcid.org/0000-0003-0400-2524 Uniwersytet Śląski w Katowicach

Monika Ładoń

iD https://orcid.org/0000-0002-7932-2728 Uniwersytet Śląski w Katowicach

${ }^{23}$ Ibidem, s. 128. 